\title{
Standardization of TP53 gene mutations analysis on oral squamous cell carcinoma from paraffin-embedded tissues
}

\author{
Padronização da análise de mutações no gene TP53 em \\ carcinomas de células escamosas de boca em material parafinado
}

José de Assis Silva Júnior ${ }^{1}$; Danielle Resende Camisasca²; Débora dos Santos Tavares³; Paulo Antônio Silvestre de Faria ${ }^{4}$;

Fernando Luiz Dias; ; Georgina Severo Ribeiro ${ }^{6}$; Lídia Maria da Fonte de Amorim7; Simone de Queiroz Chaves Lourenço ${ }^{8}$

\begin{abstract}
Introduction: The tumor protein p53 gene (TP53) is a constant target of investigation in cancer pathogenesis. Analysis by immunohistochemistry provides limited data about p53 in oral carcinogenesis, and TP53 sequencing can contribute to this analysis. However, obtaining high-quality and contamination-free deoxyribonucleic acid (DNA) for a proper amplification can be a difficult task when using paraffin-embedded tissues. Objective: Standardize DNA extraction, polymerase chain reaction (PCR) amplification and DNA sequencing techniques for TP53 mutation analysis. Material and methods: Thirty-nine cases of oral squamous cell carcinoma (OSCC) were selected from the Pathology Division of Instituto Nacional de Câncer (Inca). The DNA extraction method used was the QIAamp ${ }^{\circledR}$ DNA minikit ${ }^{\circledR}$ system. After DNA quantification by spectrophotometry, 250 ng of genetic material obtained from TP53 gene were amplified by PCR for exon 2 and by nested PCR for exon 6. Out of the total sample, 11 cases were selected for exon 2 sequencing. Results: The DNA samples presented mean concentration of $119.74 \pm 88.86 \mathrm{ng} / \mu \mathrm{l}(28.9-556.4)$ and purity of $1.69 \pm 0.18$ (1-1.9). Thirty-three (84.6\%) samples were amplified for exon 2, and all samples for exon 6 (39/100\%). Readable sequencing data were obtained in 10 (90.9\%) cases. Conclusion: Optimization of conditions for TP53 sequencing was obtained, and this will facilitate the analysis of mutations in paraffinembedded tissues, allowing molecular retrospective studies.
\end{abstract}

Key words: Tp53 gene; squamous cell carcinoma; oral cancer; DNA sequencing; methodology.

\section{INTRODUCTION}

The tumor protein 153 gene (TP53) is a tumor suppressor with roles in physiological and pathological processes ${ }^{(22,40,42-44)}$. The occurrence of mutations in TP53 is a common event in the development and progression of malignant neoplasms ${ }^{(13-15,23,31,33,41,44,45)}$ that is associated with more aggressive tumors and worse survival rates. Studies linking this molecule to oral squamous cell carcinoma (OSCC) present conflicting results ${ }^{(8,19,4245)}$.

Different techniques have been employed in the assessment of molecule p53, such as immunohistochemistry, western blotting, mRNA expression, and mutation detection of the gene ${ }^{(17,29,38,40)}$.

First submission on 16/08/13; last submission on 28/01/14; accepted for publication on 18/02/14; published on 20/04/14

1. Doctorate in Pathology from Universidade Federal Fluminense (UFF).

2. Doctorate in Pathology from UFF; associate professor at the Dentistry School of UFF in Nova Friburgo.

3. Doctorate in Materials/Biomaterials Science from Universidade Federal do Rio de Janeiro (UFRJ); associate professor at the Department of Education in Health of Universidade Federal do Sergipe (UFS).

4. Master's degree in Public Health from Fundação Oswaldo Cruz (Fiocruz); physician at the Pathology Division (Dipat) of Instituto Nacional de Câncer (Inca).

5. Doctorate in Medicine from Universidade de São Paulo (USP); full professor of Head and Neck Surgery at the Post-Graduate School of Medicine, Pontifícia Universidade Católica do Rio de Janeiro (PUC-RJ).

6. Doctorate in Pharmacy from USP; senior associate professor at the Pathology Department of UFF.

7. Doctorate in Biological Sciences from Universidade do Estado do Rio de Janeiro (UERJ); senior associate professor at the Department of Cellular and Molecular Biology of UFF.

8. Doctorate in Pathology from Faculdade de Odontologia de Bauru (FOB/USP); senior associate professor at the Pathology Department of UFF. 
The used techniques are directly related to the investigation purpose $^{(3,29)}$, and for each technique the obtainment, the storage and the type of material are important factors to ensure optimization and standardization of methodologies. Among them, immunohistochemistry is the most employed technique in the correlation between $\mathrm{p} 53$ protein and the development and progression of malignant neoplasms. However, it provides limited and contradictory data on the actual participation of this molecule in the oral carcinogenesis process $(3,8,15,38)$.

In order to better assess the involvement of TP53 gene, DNA sequencing can be used, making it possible to identify the presence and type of mutations. The technique of polymerase chain reaction (PCR) is a necessary step for this kind of analysis. However, obtaining high-quality contamination-free DNA may prove to be a difficult task, especially when using paraffin-embedded material ${ }^{(16,37,40)}$. Formol fixation, used in histopathological analyses, has several advantages, as the optimal preservation of tissues for long periods and storage of a large quantity of biological material at low cost ${ }^{20,30,36)}$. Besides, these materials are archived in hospitals for decades and represent an invaluable source of tissue for studies aimed at correlating molecular, therapeutical and clinical findings.

DNA extraction in a satisfactory amount, from previously formol-fixed paraffin-embedded samples, may be difficult due to several factors. During fixation, DNA-protein cross-links occur in tissues, which inhibit PCR amplification; hydrolysis of phosphodiester bonds, which leads to DNA fragmentation; formation of apurinic/apyrimidinic sites, which cause a gap in the sequence. Fragmentation becomes intensified with the acidic $\mathrm{pH}$ of the fixatives, temperature and fixation time, besides storage conditions ${ }^{(20,21,30,36,37)}$. In spite of the cited difficulties, it is possible to obtain adequate material for molecular analyses that may vary according to the used extraction protocol ${ }^{(2,4,5,12,27)}$.

Considering the importance of establishing specific protocols for each molecular technique, the present study aimed at standardizing analysis of TP53 mutations in OSCC from paraffinembedded material.

\section{MATERIAL AND METHODS}

A total of 39 paraffin-embedded OSCC cases preserved in paraffin in the period from January to December 1999 were selected from the archives of the Pathology Division (Dipat) of Instituto Nacional de Câncer (Inca). The present work was approved by the Ethics Committee of Inca, under no. 007/07.

\section{Sample preparation}

For each selected block, 11 tissue sections of $5 \mu \mathrm{m}$ were cut using a microtome, with disposable blades, and mounted on glass slides. All selected cases presented high percentage of tumor area $(>70 \%)$ in relation to the stroma. Hematoxylin and eosin (H\&E) staining was chosen for the first slide (in each case) to delimit the tumor area of interest, eliminating areas of necrosis, inflammation and of the tumor stroma. The delimitation for each case was carried out under mesoscopic study of the H\&E-stained slide, with the aid of a thin marker pen. This first slide served as a guide for the tissue area of interest in the other non stained slides (Figure 1). Thus, manual microdissection was performed by overlapping the previously delimited slide, with all the other sections using disposable knifes. Later, sections were stored in 1.5-ml microtubes and kept at room temperature until extraction.

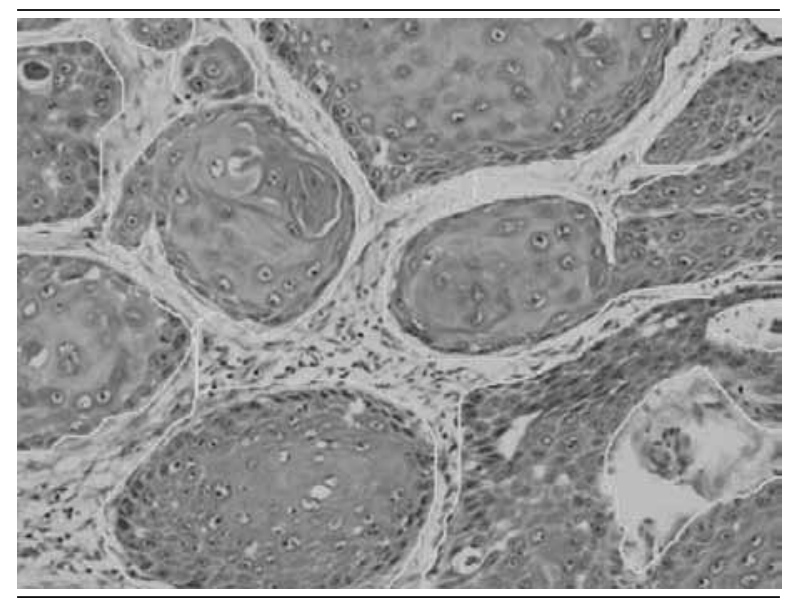

FIGURE 1 - Morphological aspect of a case of oral squamous cell carcinoma (Inca) used as a guide to select the tissue area of interest during manual microdissection (HEE; 200× magnification)

HEE: hematoxylin and eosin; Inca: Instituto Nacional de Câncer:

\section{DNA extraction}

Samples were deparaffinized in 1,200 $\mu$ xylol, being shaken for 15 seconds. Centrifugation followed at 14,000 rpm for five minutes at room temperature. The supernatant was discarded and 1,200 $\mu \mathrm{l}$ ethanol were added to the sediment to remove xylol residues. Tubes were stirred in the vortex mixer for 20 seconds, and centrifuged at 14,000 rpm during five minutes. This procedure was repeated, and tubes were inverted and placed with caps opened in the oven at $37^{\circ}$,during 15 minutes, allowing the remaining ethanol to evaporate.

The protocol for DNA extraction was carried out with the commercial system QIAamp DNA minikit ${ }^{\circledR}$ according to instructions provided by the manufacturer.

The quantity and purity of the obtained genomic DNA were determined by spectrophotometry (DU800 Spectophotometer - 
Beckman Coulter - USA). Fragmentation of the extracted genomic DNA was assessed by $0.2 \mu \mathrm{g} / \mathrm{ml}$ ethidium bromide staining on a $0.8 \%$ agarose gel electrophoresis.

\section{Polymerase chain reaction (PCR)}

PCR was used for amplification of regions including exons 2 and 6 of TP53 gene. For analysis of exon 2, sense 5'-cagggttggaagcgtctcat-3' and antisense 5'-cttcccacaggtctctgcta-3' oligonucleotides described by RELES et al. ${ }^{(34)}$ were used. Initially, tests with diverse types of reagents were conducted, and those that obtained the best results were used. The reaction mixture was composed of 20 pmol of each oligonucleotide, 1 U Taq DNA polymerase (Code \#EP0402 - Fermentas Life Science), $0.2 \mathrm{mM}$ dNTPs mixture (Code \#10297-018 - Invitrogen) and buffer $1 \times$ (Tris-HCl $75 \mathrm{mM}, \mathrm{pH} 8.8$ and $\left(\mathrm{NH}_{4}\right)_{2} \mathrm{SO}_{4} 20 \mathrm{mM}$ ), $\mathrm{MgCl}_{2} 2,0 \mathrm{mM}$ and Milli- $Q$ water in sufficient volume for $50 \mu$. With the selected sequences, a 224-pb fragment was amplified, corresponding to the region between bases 11642 and 11865 (Gene Bank, access GI: 3041866). The program used for amplification at the thermal cycler (Eppendorf - Mastercycler) was: a one-step cycle of pre-denaturation at $94^{\circ} \mathrm{C}$ for five minutes; 45 three-step cycles - denaturation at $94^{\circ} \mathrm{C}$ for 30 seconds, annealing at $60^{\circ} \mathrm{C}$ for a minute and elongation at $72^{\circ} \mathrm{C}$ for a minute -; and an additional 10-minute cycle of elongation at $72^{\circ} \mathrm{C}$.

For analysis of exon 6, we chose nested PCR, formed from a two-step amplification of the fragment from the region of interest. In the first step (reaction 1), 5'-tggttgcccagggtccccag-3' and 5'-tggagggccactgacaacca-3' ${ }^{\text {(10) }}$ oligonucleotides were used to amplify a 224-pb fragment, flanking the region between bases 13271 and 13495 (Gene Bank, access GI: 3041866). The amplification program was: a one-step cycle of pre-denaturation at $94^{\circ} \mathrm{C}$ for five minutes; 25 three-step cycles - denaturation at $94^{\circ} \mathrm{C}$ for 30 seconds, annealing at $60^{\circ} \mathrm{C}$ for a minute and elongation at $72^{\circ} \mathrm{C}$ for a minute -; and an additional 10 -minute elongation cycle at $72^{\circ} \mathrm{C}$. The generated fragment was used as a template for the second reaction, in which two oligonucleotides (5'-gcctctgattcctcactgat-3' and 5'-ttaacccctcctcccagaga-3'), anneal in internal regions, amplifying a 181-pb fragment ${ }^{(32)}$. The produced segment corresponds to the region between bases 13291 and 13471. The reaction mixture was prepared as described for exon 2, and the program of the amplified reaction of the second step were a cycle of pre-denaturation at $94^{\circ} \mathrm{C}$ for five minutes; 25 three-step cycles - denaturation at $94^{\circ} \mathrm{C}$ for 30 minutes, annealing at $60^{\circ} \mathrm{C}$ for one minute and elongation at $72^{\circ} \mathrm{C}$ for one minute -, and an additional 10-minute elongation cycle at $72^{\circ} \mathrm{C}$.
For each reaction a genomic DNA sample obtained from a peripheral blood sample (100 ng DNA) was taken as positive control, and Milli-Q water as negative control. For samples of paraffin-embedded material, the volume corresponding to 250 ng DNA was added to the reaction mixture. In the nested PCR reaction, $5 \mu \mathrm{l}$ PCR product from the first reaction was added.

The amplified products were developed after $2 \%$ agarose gel electrophoresis and staining with $0.2 \mu \mathrm{g} / \mathrm{ml}$ ethidium bromide. The electrophoretical runs were carried out at $6 \mathrm{~V} / \mathrm{cm}$ for a period of approximately 30 minutes. Amplicons size was measured with a 100-pb marker. The gel was examined in a Labmet ${ }^{\circledR}$ (ultraviolet) UV light transilluminator, and images were captured using Nucleotech ${ }^{\circledR}$ Nucleocam system.

\section{Sequencing reaction}

PCR products were purified using GFX PCR DNA Kit and Gel Band Purification ${ }^{\circledR}$ (Code 28-9034-70, GE Healthcare). This system allows the DNA fragment to be directly purified from the product obtained by PCR. In order to verify the purification success, a total of $5 \mu \mathrm{l}$ of the purified samples were visualized in $2 \%$ agarose gel.

Sequencing reaction was produced with Terminator Cycle Sequencing (Code US81090, GE Healthcare) reagent according to instructions of the manufacturer, proportionally reducing the reaction volume to $10 \mu l$. The reaction mixture was prepared using $5 \mu \mathrm{l}$ of the purified PCR product, $1 \mu \mathrm{l}$ of oligonucleotides ( $3 \mathrm{pmol}$ ) in a 96-well microplate. To this mixture $4 \mu$ of terminator mix were added, and the mixture was homogenized; then samples underwent 25 cycles of incubation at $96^{\circ} \mathrm{C}$ for 10 seconds, at $50^{\circ} \mathrm{C}$ for five seconds and at $60^{\circ} \mathrm{C}$ during four minutes in the thermal cycler. After reaction, the amplified fragments were purified with 7.5 $\mathrm{M}$ ammonium acetate and absolute ethanol. The microplate was centrifuged at a $4,000 \mathrm{rpm}$ at $4^{\circ} \mathrm{C}$ during 45 minutes. The supernatant was discarded, by inversion, and 70\% ethanol was added for hydration and salt removal. After alcohol removal, the plate was inverted and centrifuged, and sediments were ressuspended in $10 \%$ formamide. The obtained chromatograms were analyzed with the aid of program Bio Edit ${ }^{\circledR}$.

\section{RESULTS}

DNA concentration, determined by spectrophotometry, presented mean of $119.74 \pm 88.86 \mathrm{ng} / \mu \mathrm{l}$, with lower value of $28.9 \mathrm{ng} / \mu \mathrm{l}$ and upper value of $556.4 \mathrm{ng} / \mathrm{\mu l}$, and purity of $1.69 \pm$ 0.18 ranging from 1 to 1.9. In DNA evaluation by electrophoresis, 
all samples presented smearing, indicating DNA degradation. Intensity and degree of fragmentation varied among cases.

Amplification was obtained in two PCR reactions for exons 2 and 6, evidencing that the adopted extraction and amplification strategies were appropriate. Only the expected fragments were observed when analyzed in $2 \%$ agarose gel. In the reactions the enzymes Taq DNA Polymerase Brazil (Invitrogen), Platinum ${ }^{\circledR}$ Taq DNA Polymerase (Invitrogen) and Taq DNA Polymerase (Fermentas) were used. Enzymes consisting of buffers with potassium chloride $(\mathrm{KCl})$ failed at amplification. The reaction containing enzyme taq with buffer $\mathrm{NH}_{4} \mathrm{SO}_{4}$ (Code \# $\mathrm{EP} 0402$ Fermentas Life Science) was the only that obtained amplification.

Of the total analyzed samples $(n=39), 33(84.6 \%)$ were positive for exon 2, generating a 224-pb fragment. The amplification results for this region are demonstrated in Figure 2A.

For exon 6, using nested PCR, positivity was verified in all assessed cases (100\%), with the presence of 181-pb band. In just one case the result was negative for PCR amplification in the second step. However, when increasing the product of the first PCR reaction to $10 \mu \mathrm{l}$, a positive result was obtained. PCR reaction amplicon for this sequence is shown in Figure 2B.

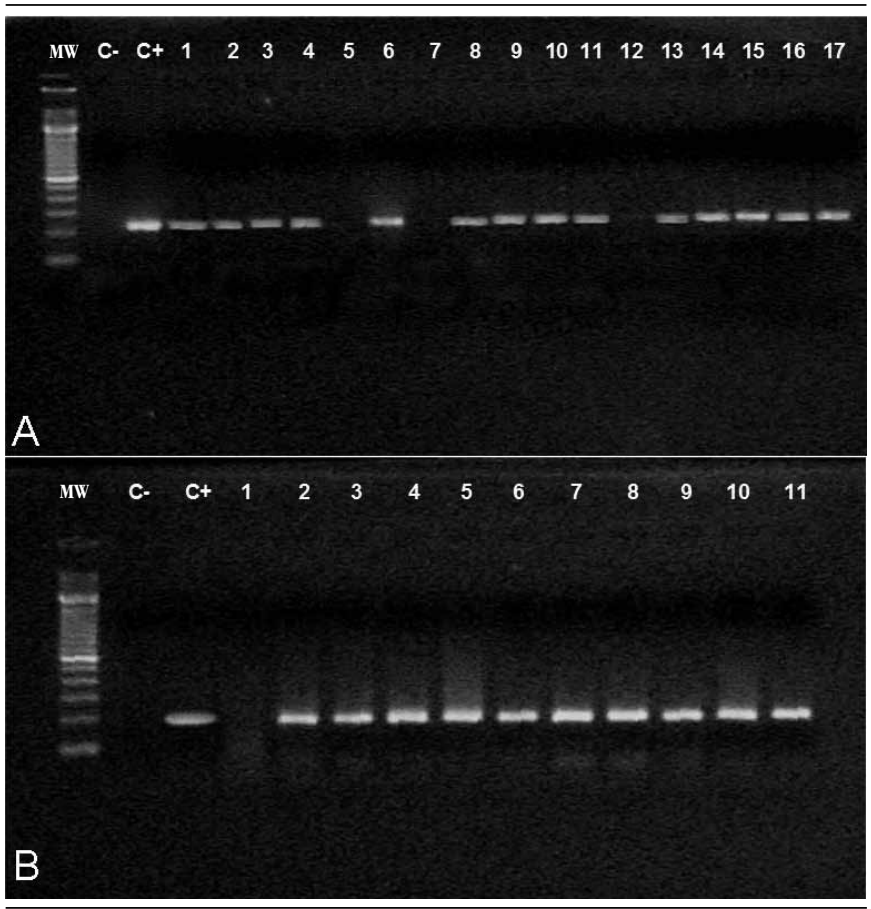

FIGURE 2 - Electrophoresis in 2\% agarose gel for amplicons of the region corresponding to exon 2 by PCR (A) and to exon 6 by nested PCR (B) of TP53 gene

MW: ladder molecular weight of $100 \mathrm{pb}$; $\mathrm{C}$-: negative control with $\mathrm{H} 20 ; \mathrm{C}+$ : positive control with DNA of peripheral blood cells. A) 1-17: paraffin-embedded samples, generating a 224-pb fragment, with absence of amplification in samples 5 and 7; B) 1-11: paraffin-embedded samples, generating a 181-pb fragment, with absence of amplification in sample 1.

DNA: deoxyribonucleic acid.
For standardization of the sequencing technique, the region including exon 2 of TP53 gene was sequenced in 11 cases. Using sense and antisense oligonucleotides, readable sequences were obtained in $10(90.9 \%)$ cases. The observed bases in the chromatogram included regions that comprised from the initial sequence of the used oligonucleotides to the final bases of the target region (Figure 3), indicating that optimization of the performing conditions of this technique were reached.

In the assessment of exon 2 sequences, a transversion caused by the replacement of thymine (T) for adenine (A) in position 11774 was identified. This base is in the TCA codon of TP53 cDNA, which encodes a serine at position 20 of the cDNA. The alteration replaces serine for threonine (Ser20Thr). The mutation was found in two of the 10 analyzed samples (Figure 4). Only in one of the analyzed cases it was not possible to perform the sequence reading.

\section{DISCUSSION}

The first step for any genetic mutation analysis is the obtainment of DNA with integrity, purity and in a satisfactory amount for the employment of the required techniques. However, the available archived materials for the conduction of studies are basically formol-fixed paraffin-embedded tissues. The main obstacles to the obtainment of this material for amplification by PCR are paraffin removal and DNA degradation ${ }^{(7,37)}$. Thus, DNA extraction is a critical step in the development of molecular studies, especially retrospective ones. This work used a retrospective sample with OSCC specimens after five years of storage, the period required for survival studies.

It is known that tissue processing causes significant alterations in DNA constitution and structure. In their recent review, Scorsato and Telles ${ }^{(37)}$ reported important factors in the phases of pre-fixation, fixation and post-fixation in relation to quality of extracted DNA from paraffin-embedded material. Although important, these factors are difficult to be controlled in retrospective or multicentric samples. In the present study, just the necessary procedures were considered for a molecular investigation after the tissue was embedded in paraffin by the standard method. On the other hand, we agree that all conducts that interfere in DNA quality must be monitored, and fixation and embedding must be done in a uniform manner at university hospitals.

The first step for a careful sequencing analysis is the selection and obtainment of the tumor sample. According to Soussi et al..$^{(40)}$, one of the main problems in the identification of somatic mutations is the contamination of tumor material with adjacent 

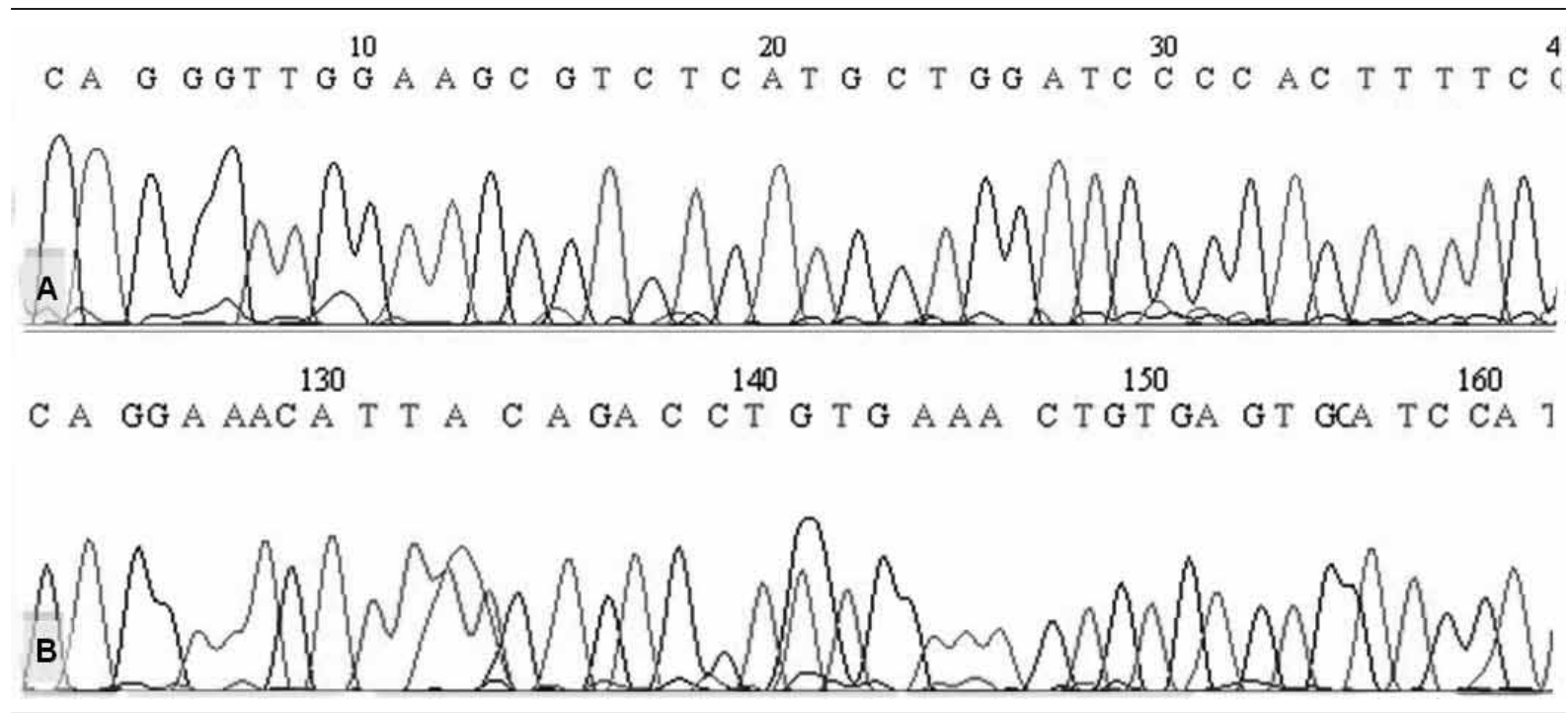

FIGURE 3 - Segment illustrating the sequence analysis of 224-pb exon 2 PCR product by the sequencing technique

A) beginning of the sequence using antisense oligonucleotides read in reverse; B) end of the amplified fragment verifying that sequencing allowed reading of the whole target region.

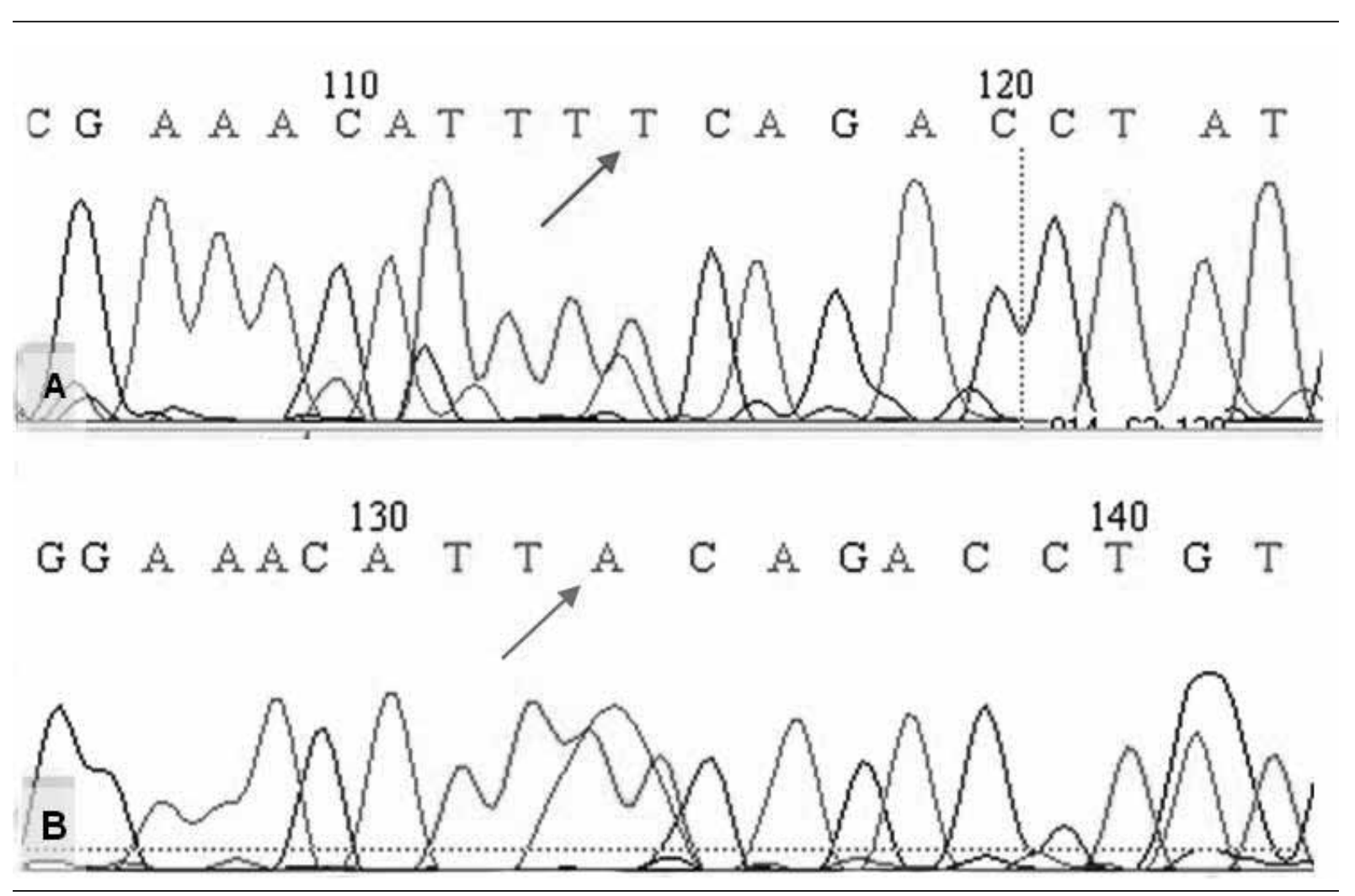

FIGURE 4 -Chromatograms obtained from DNA fragment analysis for exon 2 of TP53 gene

$A$ and B) sequence performed by the sequencing technique using sense and antisense oligonucleotides evidencing a base change represented by arrows, suggesting missense mutation.

normal tissue, stromal cells and/or inflammatory infiltrate. Considering this possibility, in this work manual microdissection was performed by removing only tumoral tissue. A similar methodology was used by Nigro et al. ${ }^{(28)}$ and Cruz et al..$^{(8)}$.
After microdissection, DNA was extracted using a silicacolumn based commercial system with affinity for DNA at high salt concentration. The usage of QIAamp DNA minikit ${ }^{\circledR}$ for DNA extraction proved a practical, rapid and useful method for archival 
material, even in small and average structured laboratories. Recent works confirm the efficiency of this DNA extraction method ${ }^{2,4,4,525,39)}$. The literature describes other methodologies for DNA purification, like Chelex ${ }^{\circledR}$, magnetic beads and home-made methods by digestion with proteinase $\mathrm{K}$ followed by extraction with phenolchloroform solution, also attaining good results ${ }^{(12,24,20,22,27,30)}$. Through this methodology, $100 \mu \mathrm{l}$ DNA solution with average concentration of $119.73 \mathrm{ng} / \mu \mathrm{l}$ was obtained, what resembles the results found in the literature ${ }^{(25,39)}$. Bielawaski et al. ${ }^{(2)}$ carried out a study assessing three DNA extraction methods of paraffinembedded material, reaching better results in the amplification of samples extracted with QIAamp DNA minikit ${ }^{\circledR}$.

In a study with samples preserved in paraffin and archived for a maximum time of 40 years, Libório et al. ${ }^{(24)}$ demonstrated that even though degraded, it is possible to obtain amplifiable DNA by PCR since the region to be amplified generates fragments of approximately $200 \mathrm{pb}$.

During the standardization steps for DNA amplification by PCR, some measures were established not to endanger reaction results. According to Soussi $e t$ al. ${ }^{(40)}$, one of the factors that may affect results for mutations analysis is the high contamination of samples handled during DNA extraction and PCR, mostly when nested PCR is used. In this sample, traditional PCR was used for exon 2 and nested PCR for exon 6, so that both methodologies were standardized. The main preventive measures against contamination were performed to minimize the possibility of obtaining false-positive results. Thus, in the procedures of PCR technique, barrier tips were used to aliquot DNA samples and PCR products; pipettes were used exclusively for PCR reagents or for DNA handling. During the opening of DNA-containing tubes, disposable paper tissues were used, and the fume hood surfaces were disinfected with $70 \%$ alcohol before being exposed to UV light for 15 minutes. The systematic and sequential way of working the samples eliminated any doubt of a possible contamination when it was time to interpret sequencing results.

In the initial phases of PCR standardization, positive amplification was not verified for any of the analyzed exons. Changes were made to the amplification programs, reagents ( $\mathrm{MgCl}_{2}$ and dNTPs) concentration, enzymes and their respective buffers, and the amount of DNA used in the technique. However, amplification was only obtained when Fermentas enzyme and the buffer containing $\left(\mathrm{NH}_{4}\right)_{2} \mathrm{SO}_{4}$ were used. It is important to cite that PCR with Fermentas enzyme and KCl buffer did not amplify DNA, suggesting an interference of buffers in this type of material. The researched literature mentions different enzymes and amplification buffers applied to reactions, but does not justify their choice $e^{(4,8,24,35,39)}$.
Other factors, besides enzymes, may influence amplification reactions, like reagents, time and temperature used in fixation and embedding during the routine tissue processing. This may justify that works using paraffin-embedded material got satisfactory results by using enzymes that did not present good results in our sample ${ }^{(4,6,39)}$.

Considering variability in the DNA concentration obtained from each sample, PCR was carried out with the volume containing 250 ng DNA. For exon 2, absence of positivity was verified in $15.4 \%(n=6)$ of the cases when an amplification by PCR was not possible, even with 500 ng DNA. Spectrophotometric analysis verified that these samples corresponded to a small group with DNA concentrations of around $30 \mathrm{ng} / \mu \mathrm{l}$. For exon 6, 100\% positivity was verified when amplification was done by nested PCR. In just one sample it was necessary to increase the amount of PCR product in the second step $(10 \mu \mathrm{l})$, when a positive result was observed. Similar results were observed by Simonato et al. ${ }^{(39)}$, who verified absence of amplification in $14.2 \%$ of the assessed cases from paraffin samples using the DNA extraction kit QIAamp ${ }^{\circledR}$ and oligonucleotides for the $\beta$ globin gene that generates a $268-\mathrm{pb}$ fragment, size similar to those of exons 2 and 6. Despite presenting higher possibility of contamination because the reaction takes place in two steps, nested PCR produced the best amplification results. In a study carried out by Demathe et $a l^{(9)}$, who compared sensitivity in detection of human papillomavirus (HPV) DNA in cases of lip carcinoma in paraffin tissue by PCR and nested PCR, an approximate six-fold increase in detection was verified when nested PCR was used. Confirming these findings, Evander et al. ${ }^{(11)}$ also observed an increase using nested PCR in a study on HPV.

The results achieved in the present work revealed that both conventional PCR and nested PCR were suitable techniques for amplifying DNA originating from paraffin-embedded material in this sample. However, factors like fragment size, material quantity and quality, and investigation purpose are important in determining the methodology to be used.

There are several techniques for analysis of TP53 mutations after PCR amplification. The use of single-strand conformation polymorphism (SSCP) analysis as a sole method or as an auxiliary to select samples for another type of assessment is constantly observed in the literature ${ }^{(6,22,26,35)}$. However, authors are unanimous to state that sequencing is the gold standard for mutation analysis, because it allows its determination ${ }^{(14,17)}$. In this study 11 cases were submitted to DNA sequence analysis, initially with the purpose of standardizing the technique. The following must be considered for interfering in the quality of sequencing results: the concentrations of oligonucleotides and of amplified DNA. For the 11 analyzed cases, readable sequences 
were observed in $90 \%$ of the cases, thus verifying an excellent standardization of this step. At the sequences analysis, two missense-type mutations were found. These mutations were identified using two-strand sequencing with sense and antisense oligonucleotides, providing more reliability for the results herein presented. From these results it was possible to identify base- and consequently amino acid-changes that are associated with exon 2 of TP53 gene, what may be useful in the understanding of neoplasms that affect the oral cavity. In order to confirm the mutation found in this study it is necessary to perform new DNA isolation, amplification and sequencing, so that these results may be validated. This high frequency $(20 \%)$ of mutation in exon 2 suggests that analysis of just exons 5 to 8 , where more frequently mutated regions are located (hot spots), may cause underestimation of the actual mutation frequency in TP53 gene.

\section{CONCLUSION}

This study reached the optimization of conditions for molecular methods of DNA isolation, PCR amplification, and sequencing reaction in formol-fixed paraffin-embedded tissues, allowing the conduction of retrospective molecular studies, such as TP53 mutation analysis.

\section{RESUMO}

Introdução: O gene TP53 (proteina tumoralp53) éalvo constante de investigação na patogênese do câncer. A imuno-bistoquímica fornece dados limitados na análise de 553 no processo da carcinogênese bucal e o sequenciamento de TP53 pode contribuir nessa investigação. Contudo, a obtenção de ácido desoxirribonucleico (DNA) com qualidadepara amplificação e livre de contaminação pode constituir uma tarefa difícil na utilização de material parafinado. Objetivo: Padronizar as técnicas de extração de DNA, amplificação por reação em cadeia da polimerase (PCR) e sequenciamento para a análise de mutações em TP53. Material e métodos: Foram selecionados 39 casos de carcinomas de células escamosas bucal da Divisão de Patologia do Instituto Nacional de Câncer (Inca). O DNA foi extraído utilizando o sistema comercial QIAamp ${ }^{\circledR}$ DNA minikit ${ }^{\circledR}$. Após quantificação do DNA por espectrofotometria, 250 ng de amostra foram amplificados pela técnica de PCR para o éxon 2 epor nested PCRpara o éxon 6 do gene TP53. Da amostra total, 11 casos foram selecionados para a padronização da reação de sequenciamento do éxon 2. Resultados: As amostras de DNA apresentaram concentração média de 119,74 $\mathrm{ng} / \mu \mathrm{l} \pm 88,86(28,9-556,4 \mathrm{ng} / \mu \mathrm{l})$ e pureza de 1,69 \pm 0,18 (1-1,9). Do total das amostras analisadas, 33 (84,6\%) foram amplificadas para o éxon 2, e todas (39/100\%), para o éxon 6. No sequenciamento do éxon 2 obtiveram-se sequências passíveis de leitura em 10 (90,9\%) casos. Conclusão: A otimização das condições para o sequenciamento de TP53 foi obtida, o que facilitará a análise de mutações em tecidos parafinados, permitindo a realização de estudos moleculares retrospectivos.

Unitermos: gene TP53; carcinoma de células escamosas; câncer da boca; inclusão em parafina; sequenciamento de DNA; metodologia.

\section{REFERENCES}

1. BIDAUD, P. et al. Expression of p53 family members and CD 44 in oral squamous cell carcinoma (OSCC) in relation to tumorigenesis. Histol Histopathol, v. 25, n. 3, p. 331-9, 2010 .

2. BIELAWASKI, K. et al. The suitability of DNA extracted from formalinfixed, paraffin-embedded tissues for double differential polymerase chain reaction analysis. Int J Mol Med, v. 8, n. 5, p. 573-8, 2001.

3. BLONS, H.; LAURENT-PUIG, P. TP53 and head and neck neoplasms. Hum Mutat, v. 21, n. 3, p. 252-7, 2003.
4. CAO, W. et al. Comparison of methods for DNA extraction from paraffin-embedded tissues and buccal cells. Cancer Detect Prev, v. 27, n. 5 , p. 397-404, 2003.

5. CHAN, P. K. et al. Evaluation of extraction methods from paraffin wax embedded tissues for PCR amplification of human and viral DNA.J Clin Pathol, v. 54, n. 5, p. 401-3, 2001.

6. CHAVES, A. C. et al. Characterization of p53 gene mutations in a Brazilian population with oral squamous cell carcinomas. Inter J Oncol, v. 24, n. 2, p. 295-303, 2004 
7. COOMBS, N. J.; GOUGH, A. C.; PRIMROSE, J. N. Optimisation of DNA and RNA extraction from archival formalin-fixed tissue. Nucleic Acids Res, v. 27, n. 16, p. 12, 1999.

8. CRUZ, I. B. et al. Specific $\mathrm{p} 53$ immunostaining patterns are associated with smoking habits in patients with oral squamous cell carcinomas. J Clin Pathol, v. 55, n. 11, p. 834-40, 2002.

9. DEMATHE, A. et al. Comparação entre dois métodos de detecção de DNA de papilomavírus humano em carcinoma epidermoide de lábio. J Bras Patol Med Lab, v. 46, n. 2, p. 85-90, 2010.

10. EACHKOTI, R. et al. BRCA1 and TP53 mutation spectrum of breast carcinoma in an ethnic population of Kashmir, an emerging high-risk area. Cancer Lett, v. 248, n. 2, p. 308-20, 2007.

11. EVANDER, M. et al. Comparison of a one-step and a two-step polymerase chain reaction with degenerate general primers in a population-based study of human papillomavirus infection in young Swedish women.J Clin Microbiol, v. 30, n. 4 p. 987-92, 1992.

12. FERNANDES, J. V. et al. Comparação de três protocolos de extração de DNA a partir de tecido fixado em formol e incluído em parafina. J Bras Patol Med Lab, v. 40, n. 3, p. 141-6, 2004.

13. GASCO, M.; CROOK, T. The 553 network in head and neck cancer. Oral Oncol, v. 39, n. 3, p. 222-31, 2003.

14. GIGLIA-MARI, G.; SARASIN, A. TP53 mutations in human skin cancers. Hum Mutat, v. 21, n. 3, p. 217-28, 2003.

15. GIROD, S. C.; KRUEGER, G.; PAPE, H. D. p53 and Ki 67 expression in preneoplastic and neoplastic lesions of the oral mucosa. Int J Oral Maxillofac Surg, v. 22, n. 5, p. 285-8, 1993.

16. GOUVEIA, G. R. et al. Comparação de três protocolos distintos para extração de RNA de amostras fixadas em formalina e emblocadas em parafina.J Bras Patol Med Lab, v. 47, n. 6, p. 649-54, 2011.

17. HAINAUT, P.; WIMAN, K. G. 25 Years of $p 53$ Research. Netherlands, Springer, 2005.

18. HEGDE, P. U. et al. Tumor angiogenesis and p53 mutations: prognosis in head and neck cancer. Arch Otolaryngol Head Neck Surg, v. 124, n. 1, p. 80-5, 1998.

19. HSIEH, L. L. et al. Characteristics of mutations in the p53 gene in oral squamous cell carcinoma associated with betel quid chewing and cigarette smoking in Taiwanese. Carcinogenesis, v. 22, n. 9, p. 1497-503, 2001.

20. HUIJSMANS, C. J.et al. Comparative analysis of four methods to extract DNA from paraffin-embedded tissues: effect on downstream molecular applications. BMC Res Notes, v. 3, n. 239, p. 1-9, 2010.

21. ISOLA, J. et al. Analysis of changes in DNA sequence copy number by comparative genomic hybridization in archival paraffin-embedded tumor samples. Am J Pathol, v. 145, n. 6, p. 1301-8, 1994.

22. KOZOMARA, R. et al. p53 mutations and human papillomavirus infection in oral squamous cell carcinomas: correlation with overall survival.J Craniomaxillofac Surg, v. 33, n. 5, p. 342-8, 2005.

23. LEVINE, A. J.; MOMAND, J.; FINLAY, C. A. The p53 tumour suppressor gene. Nature, v. 351, n. 6326, p. 453-6, 1991.

24. LIBÓRIO, T. N. et al. Evaluation of the genomic DNA extracted from formalin-fixed, paraffin-embedded oral sample archived for the 40-years. J Bras Patol Med Lab, v. 41, n. 6, p. 405-10, 2005.
25. MESQUITA, R. A. et al. Avaliação de três métodos de extração de DNA de material parafinado para amplificação de DNA genômico pela técnica da PCR. Pesqui Odontol Bras, v. 15, n. 4, p. 314-9, 2001.

26. NAGAI, M. A. et al. TP53 mutations in upper aerodigestive squamous cell carcinomas from a group of Brazilian patients. Am J Surg, v. 170, n. 5, p. 492-4, 1995.

27. NASCIMENTO, E. M. et al. Protocolo da extração de DNA de material parafinado para análise de microssatélite em leiomioma. J Bras Patol Med Lab, v. 39, n. 3, p. 1-6, 2003.

28. NIGRO, J. M. et al. Detection of 1p and 19q loss in oligodendroglioma by quantitative microsatellite analysis, a real-time quantitative polymerase chain reaction assay. Am J Pathol, v. 158, n. 4, p. 1253-62, 2001.

29. NYLANDER, K.; DABELSTEEN, E.; HALL, P. A. The p53 molecule and its prognostic role in squamous cell carcinomas of the head and neck.J Oral Pathol Med, v. 29, n. 9, p. 413-25, 2000.

30. OKELLO J. B. et al. Comparison of methods in the recovery of nucleic acids from archival formalin-fixed paraffin-embedded autopsy tissues. Anal Biochem, v. 400, n. 1, p. 110-7, 2010.

31. PATERSON, I. C.; EVESON, J. W.; PRIME, S. S. Molecular changes in oral cancer may reflect aetiology and ethnic origin. Eur J Cancer B Oral Oncol, v. 32B, n. 3, p. 150-3, 1996.

32. POOART, J.; LIMPAIBOON, T.; LULITANOND, V. Improved nonisotopic PCR-SSCP for screening of p53 mutations. Clin Biochem, v. 32, n. 3 , p. 233-5, 1999.

33. RAYBAUD-DIOGÈNE, H. et al. p53 overexpression in head and neck squamous cell carcinoma: review of the literature. Oral Oncol, v. 32B, n. 3, p. 143-9, 1996.

34. RELES, A. et al. Correlation of p53 mutations with resistance to platinum-based chemotherapy and shortened survival in ovarian cancer. Clin Cancer Res, v. 7, n. 10, p. 2984-97, 2001.

35. SARANATH, D. et al.p53 inactivation in chewing tobacco-induced oral cancers and leukoplakias from India. Oral Oncol, v. 35, n. 3, p. 242-5, 1999 .

36. SCHANDER, C.; KENNETHM, K. M. DNA, PCR and formalinized animal tissue - a short review and protocols. Organisms Diversity $\mathcal{E}$ Evolution, v. 3, n. 3, p. 195-205, 2003.

37. SCORSATO, A. P.; TELLES, J. E. Q. Fatores que interferem na qualidade do DNA extraído de amostras biológicas armazenadas em blocos de parafina.J Bras Patol Med Lab, v. 47, n. 5, p. 541-8, 2011.

38. SILVA JUNIOR, J. A. et al. Análise comparativa da imunoexpressão da proteína p53 (clones D0-7 e PAb-240) em carcinomas de células escamosas intrabucais e labiais. J Bras Patol Med Lab, v. 45, n. 4, p. 335-42, 2009.

39. SIMONATO, L. E. et al. Avaliação de dois métodos de extração de DNA de material parafinado para amplificação em PCR. J Bras Patol Med $L a b$, v. 43, n. 2, p. 121-7, 2007

40. SOUSSI, T. et al. Locus-specific mutation databases: pitfalls and good practice based on the 553 experience. Nat Rev Cancer, v. 6, n. 1, p. 83-90, 2006.

41. SOUSSI, T. Focus on the p53 gene and cancer: advances in TP53 mutation research. Hum Mutat, v. 21, n. 3, p. 173-5, 2003. 
42. TASSONE, P. et al.p53-based therapeutics for head and neck squamous cell carcinoma. Oral Oncol, v. 49, n. 8, p. 733-7, 2013.

43. VOGELSTEIN, B.; KINZLER, K. W. Cancer genes and the pathways they control. Nat Med, v. 10, n. 8, p. 789-99, 2004.
44. VOUSDEN, K. H.; LANE, D. P. p53 in health and disease. Nat Rev Mol Cell Biol, v. 8, n. 4, p. 275-83, 2007.

45. YAMAZAKI, Y. et al. Specific p53 mutations predict poor prognosis in oral squamous cell carcinoma. Oral Oncol, v. 39, n. 2, p. 163-9, 2003. 